\title{
OCCASIONAL NOTES
}

\section{V.-THE GENERIC NAME CREPIDOGASTER.}

In consequence of removal from Sydney I was unable to see proofs of my paper "Descriptions of and Notes on some Australian and Tasmanian Fishes," published in the preceding number of the "Records." In writing, I had overlooked the fact that the name Crepidogaster is not available in Fishes.

On page 201, I followed Günther in using Crepidoyaster for a genus in Gobiesocidæ, but this name, applied to fishes in 1861, was previously used by Boheman (1848), ${ }^{2}$ for a genus of Coleopterous insects.

I therefore propose the name ASPASMOGASTER as a substitute for Crepidogaster in Fishes.

Canterbury Museum,

EDGtR R. WAITE.

Christchurch, N.Z.

19th July, 1906.

\section{VI.-NOTE oN AN UNUSUAL SET OF STONE PLOVER'S EGGS.}

The Curator handed me for examination, from Mr. Norman Etheridge's collection, a remarkable set of eggs of the StonePlover (Edicnemus grallarius, Lath.). It comprises for this species the unusual number of four eggs. They were fresh, and all found together in a scantily grass-lined depression in the earth at Bargo by Mr. G. Hambridge, on the 20th September, 1906. Presumably it is the result of two females laying in the same nest for the eggs are of two fairly distinct types varying in the inten-

1 Waite-Rec. Austr. Mus., vi., 3, 1906, pp. 194 and 201.

2 Boheman-Ins. Caffr.. i., 1848, p. 68, fide Gemminger and Harold. 


\section{$2 \mathrm{BHL}$ Biodiversity Heritage Library}

Waite, Edgar R. 1907. "Occasional notes. V. The generic name Crepidogaster." Records of the Australian Museum 6, 315.

https://doi.org/10.3853/j.0067-1975.6.1907.1014.

View This Item Online: $\underline{\text { https://www.biodiversitylibrary.org/item/31431 }}$

DOI: https://doi.org/10.3853/j.0067-1975.6.1907.1014

Permalink: https://www.biodiversitylibrary.org/partpdf/15851

\section{Holding Institution}

Harvard University, Museum of Comparative Zoology, Ernst Mayr Library

\section{Sponsored by}

Harvard University, Museum of Comparative Zoology, Ernst Mayr Library

\section{Copyright \& Reuse}

Copyright Status: NOT_IN_COPYRIGHT

This document was created from content at the Biodiversity Heritage Library, the world's largest open access digital library for biodiversity literature and archives. Visit BHL at https://www.biodiversitylibrary.org. 